Article Type: Research Paper

\title{
The Effect of Halal Foods Awareness on Purchase Decision with Religiosity as a Moderating Variable
}

\author{
Inar Anggraini ${ }^{1}$ and Diah Setyawati Dewanti ${ }^{1}$
}

\begin{abstract}
This study aims to examine and explain the effect of halal food awareness on purchase decisions with religiosity as a moderating variable. The sample in this study is Muslim consumers in Indonesia and Thailand. Purposive sampling technique was applied by criteria of samples required is Muslim consumers in Indonesia and Thailand. The number of samples is 200 respondents, included 150 Indonesian respondents and 50 Thai respondents. The analysis is done using Moderated Regression Analysis (MRA) with SPSS 23.0 software. The finding of this study shows that respondent has a high-level awareness of halal foods in Indonesia and Thailand. Halal food awareness has a positive and significant impact on purchase decisions for Muslims living in Indonesia. Halal food awareness has a positive and significant impact on purchase decisions for Muslims living in Thailand. Finally, the higher level of religiosity cannot strengthen the effect of awareness on a purchase decision.
\end{abstract}

Keywords: Halal Food Awareness; Religiosity; Purchase Decision.

DOI: 10.18196/jerss.040116

\section{CITATION:}

Anggraini, I. \& Dewanti, D. S. (2020). The Effect of Halal Foods Awareness on Purchase Decision with Religiosity as a Moderating Variable. Journal of Economics Research and Social Sciences, 4(1), 17-29.

\section{Introduction}

Religious beliefs play a significant part in sculpting social behavior. Differences in religious affiliations tend to influence the way people live, the choices they make, what they eat, and whom they associate with. According to (Soesilowati, 2010) Muslim respondents consistently put a high priority on the halal issue when they purchase food, buy meat, or select a restaurant. Muslims tend to consider halal food products when choosing food or restaurant. Globally, the halal food industries estimated growth rate is $7 \%$ annually (Aziz \& Chock, 2013).

One of the major concerns of Islamic teaching for its believers is to consume all products that are permissible (halal) and good (thayyib) according to the relevant specifically the Quran and the Hadith. This Halal term is already taught by the parent since they were young. Halal is derived from the Arabic word al-halal, which means permissible or lawful. The term halal means "things and activities that are permitted by the Syariah.

One phenomenon that has occurred is the existence of noodle products originating from South Korea "Samyang Noodle" which has pork DNA content. Quoted from Tribunnews.com that based on the order letter dated June 15, 2017, BPOM mentioned the reason for the withdrawal of 
noddle products from South Korea because they contained pork DNA fragments (Arsyam, 2018). This phenomenon makes people in Indonesia become aware of purchased food products, especially products from foreign countries.

According to (Golnaz, et al., 2010) the halal concept emphasizes safety, hygiene, and wholesomeness of food. It also provides an excellent platform for healthy eating. Consideration of the place and process of the animals being slaughtered and most importantly, the condition of these animals would not endanger the health of diners, are a prime focus of what Halal is all about. Therefore, Muslims are increasingly aware that choosing halal products is very important not only to follow the rules of religion but to obtain food products that comply with health standards. Research in accordance with these opinions is (Arinilhaq, 2017) which has explained the result that halal awareness has a positive and significant impact on purchase intention.

Such conditions occur where most of the populations are Muslims. This also happens in countries where Muslim minorities like Thailand. According to (Sateemae, et al., 2015) Muslim communities comprise approximately $5 \%$ of the total population of Thailand. But Thailand is one country that has potential in food which can be a hub of Halal food. Since Thailand has advantages in raw materials. However, Muslims in Muslim minority countries are certainly more difficult to find halal products, therefore we need a high level of religiosity to increase the awareness of Muslims in Thailand to decide to buy halal food products.

According to (Minton, et al., 2015) religiosity and the values associated with moral priorities are important, yet overlooked, predictors of special food preferences. Prior research has identified religiosity as a moderating variable is (Machali, et al., 2013) which shows the result that religiosity can be a variable that can increase or decrease the relationship between halal food awareness and purchase decision. As a moderating variable, a low level of religiosity will reduce the relationship between halal food awareness and purchase decision. But, the high level of religiosity will increase the relationship between halal food awareness and purchase decision.

This research focuses on the relationship between halal food awareness and purchase intention with religiosity as a moderating variable in Indonesian markets moreover compared Thai halal food products. In the background of this research explained how the differences between halal food awareness in Muslim-majority countries and Muslim minority countries.

\section{Literature Review and Hypotheses Development}

\section{Halal Food}

Halal means permitted or lawful follows as Islamic laws. Food defined as anything eaten or taken orally to the body as a source of energy (Mathew, et al., 2014). Halal foods are foods that are allowed under Islamic dietary guidelines. Halal foods not only limited 
ideas for Muslims but also provide to everyone because the main importance of Halal food is foods are cleanness in every proves and follow from Halal standard which might differ in each country.

\section{Halal food Awareness}

Awareness comprises a human's perception and cognitive reaction to a condition or event. Awareness does not necessarily imply understanding, just an ability to be conscious of, feel, or perceive. According to Ambar and Bakar (2013) cited by (Machali, et al., 2013), the literal meaning of the word "awareness" in the halal context is to have a special interest in or experience of something and/or being well informed of what is happening at the present time on halal food, drinks, and products.

\section{Purchase Decision}

The purchase decision is the selection of two alternative choices or more consumers on purchase (Schiffman \& Kanuk, 2010). Purchase decision-making is the stage where the consumer purchase product. For measuring the purchase decision, mentioned that the purchase decision process consists of five stages: introduction needs, information search, evaluation of alternatives, purchase decision, and behavior after purchase (Armstrong, 2012).

\section{Religiosity}

Religiosity is something very important in human life. Religiosity embodied in various sides of human life. Religious activity not only occurs when someone performs ritual behavior (worship) but also when doing any other activity that is driven by supernatural forces. Not only with respect to the activities that looked and could see the eyes, but also activities that do not appear to occur in one's heart. People with a higher level of religiosity were significantly more likely to feel a greater connection with the universe than their counterparts with lower lever religiosity (Momtaz, et al., 2011).

\section{Hypothesis}

Based on this research the researcher can determine the hypothesis of Halal Food Awareness to Purchase Decision with Religiosity as a moderating variable.

\section{H1: Respondents have a high-level awareness of halal foods}

H2: Halal foods awareness has a positive and significant impact on purchase decision for Muslims living in Indonesia

H3: Halal foods awareness has a positive and significant impact on purchase decision for Muslims living in Thailand 
H4: The higher the degree of religiosity, the stronger the effect of awareness on the purchase decision.

\section{Conceptual Framework}

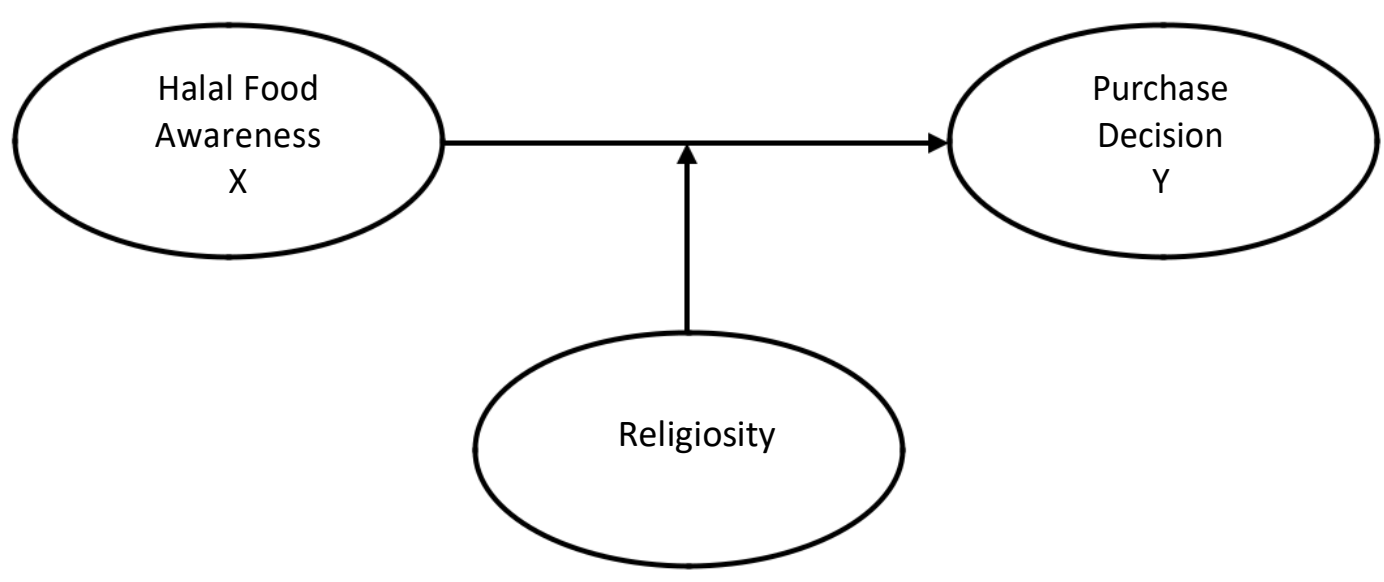

Figure 2.1 Research Model

\section{Research Method}

This research in testing the hypothesis seeks to explain causal relationships between several variables with the causality approach. This research conducted in Yogyakarta and Thailand. The sample data technique used is non-probability sampling, where the sampling technique does not provide the equal opportunity for each element or member of the population to be selected as a sample. The type of non-probability sampling used is a purposive sampling (also known as judgment, selective or subjective sampling). The sample used in this research is based on the researchers' assumptions, where the sample used was 150 samples from Indonesian respondents and 50 samples from Thai respondents. However, these 200 samples are in accordance with the provisions of (Hair, et al., 1998) which explain that representative samples range from 100-200 samples. Technique data collection used to collect data that meets established standards. The tool used to obtain data is a questionnaire by using Google Forms Survey applications.

\section{Result and Discussion}

\section{Demographic Characteristics of Respondents}

\section{Gender}


The Effect of Halal Foods Awareness on Purchase Decision ...

Table 1 Demographic Background of Indonesian Respondents Classified by Gender

\begin{tabular}{ccc|}
\hline Gender & Frequency & Percentage (\%) \\
\hline Male & 60 & 40 \\
Female & 90 & 60 \\
Total & 150 & 100 \\
\hline
\end{tabular}

Source: Attachment 3

The result from Table 1 shows that the major of Indonesian respondents in this group are female (90 respondents) who accounted for $60 \%$ of the total respondents. The rest are 60 male respondents who accounted for $40 \%$ of the total respondents.

Table 2 Demographic Background of Thai Respondents Classified by Gender

\begin{tabular}{ccc}
\hline Gender & Frequency & Percentage (\%) \\
\hline Male & 22 & 44 \\
Female & 28 & 56 \\
Total & 50 & 100 \\
\hline
\end{tabular}

Source: Attachment 3

The comparison between male and female respondents in this research for both Indonesian and Thai respondents was not too different. The proportion of male and female is not too far, so even though the majority are female respondents, male respondents are also still quite a lot.

\section{Age}

Table 3 Demographic Background of Indonesian Respondents Classified by Age

\begin{tabular}{lccc} 
& Age & Frequency & Percentage $(\%)$ \\
\hline $17-23$ years & 88 & 69.7 \\
$24-30$ years & 52 & 34.7 \\
$31-37$ years & 7 & 4.7 \\
$38-44$ years & 1 & 0.7 \\
$45-51$ years & 2 & 1.3 \\
Total & 150 & 100 \\
\hline
\end{tabular}

Source: Attachment 3

Table 4 Demographic Background of Thai Respondents Classified by Age

\begin{tabular}{lccc} 
& Age & Frequency & Percentage $(\%)$ \\
\hline $17-23$ years & 10 & 20 \\
$24-30$ years & 33 & 66 \\
$31-37$ years & 4 & 8 \\
$38-44$ years & 1 & 2 \\
$45-51$ years & 2 & 4 \\
Total & 50 & 100 \\
\hline
\end{tabular}

\section{Source: Attachment 3}

The age difference of the majority of respondents in Indonesia and Thailand is indicated because Indonesian respondents are respondents who are still studying at undergraduate level, so Indonesian respondents are mostly aged between 17 to 23 years. But the majority of Thai respondents are people who are continuing to study at postgraduate, so the age of Thai respondents is older than Indonesian respondents. 


\section{Educational Background}

Table 5 Demographic Background of Indonesian Respondents Classified by Educational Background

\begin{tabular}{lcc}
\hline \multicolumn{1}{c}{ Educational Background } & Frequency & Percentage (\%) \\
\hline High School & 55 & 36.7 \\
Diploma & 10 & 6.7 \\
Bachelor's Degree & 72 & 48 \\
Master's Degree & 11 & 7.3 \\
Doctorate & 2 & 1.3 \\
Total & 150 & 100 \\
\hline
\end{tabular}

Source: Attachment 3

Table 6 Demographic Background of Thai Respondents Classified by Educational Background

\begin{tabular}{lcc}
\multicolumn{1}{c}{ Educational Background } & Frequency & Percentage (\%) \\
\hline High School & - & 0 \\
Diploma & - & 0 \\
Bachelor's Degree & 20 & 40 \\
Master's Degree & 25 & 50 \\
Doctorate & 5 & 10 \\
Total & 50 & 100 \\
\hline
\end{tabular}

Source: Attachment 3

As previously explained, the majority of respondents in Indonesia are undergraduate students, so their later education is mostly High School, while Thai respondents are postgraduate students, as long as the majority of the latter education is bachelor's degree.

\section{Income}

Table 7 Demographic Background of Indonesian Respondents Classified by Income

\begin{tabular}{lccc}
\hline \multicolumn{1}{c}{ Income } & Frequency & Percentage (\%) \\
\hline Rp 1.000.000 or less & 39 & 26.0 \\
Rp 1.000.000-Rp 1.999.999 & 32 & 21.3 \\
Rp 2.000.000-Rp 2.999.999 & 26 & 17.3 \\
Rp 3.000.000-4.000.000 & 22 & 14.7 \\
more than Rp 4.000.000 & 31 & 20.7 \\
Total & 150 & 100.0 \\
\hline
\end{tabular}

Source: Attachment 3

Table 8 Demographic Background of Thai Respondents Classified by Income

\begin{tabular}{lcc}
\hline \multicolumn{1}{c}{ Income } & Frequency & Percentage (\%) \\
\hline Rp 1.000.000 or less & 3 & 6 \\
Rp 1.000.000-Rp 1.999.999 & 4 & 8 \\
Rp 2.000.000-Rp 2.999.999 & 4 & 8 \\
Rp 3.000.000-4.000.000 & 10 & 20 \\
more than Rp 4.000.000 & 29 & 58 \\
Total & 50 & 100 \\
\hline
\end{tabular}

Source: Attachment 3 
The result from Table 8 shows that the majority of Thai respondents have income more than $\mathrm{Rp} 4.000 .000$ (58\%), followed by income in the range $\mathrm{Rp} 3.000 .000-3.999 .999$ (20\%), income in the range $\mathrm{Rp} 1.000 .000-\mathrm{Rp} 1.999 .999$ (8\%), income in the range $\mathrm{Rp}$ $2.000 .000-R p 2.999 .999(8 \%)$, and income in the range $R p 1.000 .000$ or less (6\%).

\section{Validity Analysis}

Table 9 The Result of Validity Analysis

\begin{tabular}{|c|c|c|c|c|}
\hline Variable & Instrument & Sig. & alpha & Description \\
\hline Halal Food & HA1 & 0,000 & 0,05 & Valid \\
\hline \multirow[t]{6}{*}{ Awareness } & $\mathrm{HA} 2$ & 0,000 & 0,05 & Valid \\
\hline & HA3 & 0,000 & 0,05 & Valid \\
\hline & HA4 & 0,000 & 0,05 & Valid \\
\hline & HA5 & 0,000 & 0,05 & Valid \\
\hline & HA6 & 0,000 & 0,05 & Valid \\
\hline & HA7 & 0,000 & 0,05 & Valid \\
\hline \multirow[t]{21}{*}{ Religiosity } & R1 & 0,016 & 0,05 & Valid \\
\hline & R2 & 0,000 & 0,05 & Valid \\
\hline & R3 & 0,016 & 0,05 & Valid \\
\hline & R4 & 0,000 & 0,05 & Valid \\
\hline & R5 & 0,000 & 0,05 & Valid \\
\hline & R6 & 0,000 & 0,05 & Valid \\
\hline & R7 & 0,000 & 0,05 & Valid \\
\hline & R8 & 0,000 & 0,05 & Valid \\
\hline & R9 & 0,000 & 0,05 & Valid \\
\hline & R10 & 0,000 & 0,05 & Valid \\
\hline & R11 & 0,000 & 0,05 & Valid \\
\hline & R12 & 0,000 & 0,05 & Valid \\
\hline & R13 & 0,000 & 0,05 & Valid \\
\hline & R14 & 0,000 & 0,05 & Valid \\
\hline & R15 & 0,000 & 0,05 & Valid \\
\hline & R16 & 0,000 & 0,05 & Valid \\
\hline & R17 & 0,000 & 0,05 & Valid \\
\hline & R18 & 0,000 & 0,05 & Valid \\
\hline & R19 & 0,000 & 0,05 & Valid \\
\hline & $\mathrm{R} 20$ & 0,000 & 0,05 & Valid \\
\hline & $\mathrm{R} 21$ & 0,000 & 0,05 & Valid \\
\hline Purchase & PD1 & 0,000 & 0,05 & Valid \\
\hline \multirow[t]{7}{*}{ Decision } & PD2 & 0,000 & 0,05 & Valid \\
\hline & PD3 & 0,000 & 0,05 & Valid \\
\hline & PD4 & 0,000 & 0,05 & Valid \\
\hline & PD5 & 0,000 & 0,05 & Valid \\
\hline & PD6 & 0,000 & 0,05 & Valid \\
\hline & PD7 & 0,000 & 0,05 & Valid \\
\hline & PD8 & 0,000 & 0,05 & Valid \\
\hline
\end{tabular}

Source: Attachment 2

Based on Table 9, the result of the validity test can show that all instruments used to measure the variables in this research have significance value less than 0,05 . According to (Ghozali, 2016), that all instruments used in this study are valid. 


\section{Reliability Test}

Table 10 Reliability Analysis

\begin{tabular}{|c|c|}
\hline Construct & Cronbach's Alpha \\
\hline Halal Food Awareness & 0,785 \\
\hline Religiosity & 0,885 \\
\hline Purchase Decision & 0,838 \\
\hline
\end{tabular}

Source: Attachment 2

Based on Table 10, reliability analysis showed that all variables (halal food awareness, religiosity, and purchase decision) fulfilled the required Cronbach's alpha-level of $>0,6$. According to Ghozali (2016), Cronbach's alpha values are above 0.6 which indicates that the internal consistency reliability of the measures used in this study can be considered to be good.

\section{Hypothesis 1}

The first hypothesis was respondents have a high-level awareness toward halal foods.

Following table 11 summarizes the results of the first hypothesis.

Table 11 Percentage of Responses Related to Awareness Toward Halal Foods

\begin{tabular}{|c|c|c|c|}
\hline Total Score & Level of Awareness & Frequency & Percentage (\%) \\
\hline $29-35$ & Very High & 107 & 53.5 \\
\hline $22-28$ & High & 78 & 39.0 \\
\hline $15-21$ & Moderate & 14 & 7.0 \\
\hline $8-14$ & Low & 1 & 0.5 \\
\hline $1-7$ & Very Low & - & 0 \\
\hline
\end{tabular}

Source: Attachment 4

Based on table 11 indicates that $53.5 \%$ of respondents have a very high level of awareness, followed by $39 \%$ of respondents a have high level of awareness, $7 \%$ of respondents have a moderate level of awareness and $0,5 \%$ of respondents have a low level of awareness. Overwhelmingly more than $90 \%$ of respondents report having a high or very high level of awareness of halal foods. This provides support $\mathrm{H} 1$ which indicate that the halal food awareness among respondent in Indonesia and Thailand is significantly high.

\section{Hypothesis 2}

The second hypothesis of the model requires a test of the expected positive and significant effect of awareness on purchase decisions for Muslims living in Indonesia. Table 12 present the result of hypothesis 2 . 
Table 12 The Regression Result of Indonesian Respondents

\begin{tabular}{lcccc|}
\multicolumn{1}{c}{$\begin{array}{c}\text { Independent } \\
\text { Variable }\end{array}$} & \multicolumn{1}{c}{$\begin{array}{c}\text { Standardized } \\
\text { Coefficients Beta }\end{array}$} & t' $^{\prime}$ & Sig & Description \\
\hline $\begin{array}{l}\text { Halal Food } \\
\begin{array}{l}\text { Awareness } \\
(\mathrm{X})\end{array}\end{array}$ & 0,667 & 10,881 & 0,000 & $\begin{array}{l}\text { Positive and } \\
\text { Significant }\end{array}$ \\
\hline
\end{tabular}

Source: Attachment 5

Based on table 12, the result of the hypothesis 2 test shown, the effect of halal food awareness on purchase decision for Muslims living in Indonesia has positive and significant $(\mathrm{t}=10,881$, Sig. $=0,000<0,05)$. The result provides strong support for hypothesis 2 .

\section{Hypothesis 3}

The Third hypothesis of the model requires a test of the expected positive and significant effect of awareness on purchase decisions for Muslims living in Thailand. Table 5.8 present the result of hypothesis 3 .

Table 13 The Regression Result of Thai Respondents

\begin{tabular}{|c|c|c|c|c|}
\hline $\begin{array}{c}\text { Independent } \\
\text { Variable }\end{array}$ & $\begin{array}{c}\text { Standardize } \\
\text { Coefficients Beta }\end{array}$ & $t^{\prime}$ & Sig & Description \\
\hline $\begin{array}{l}\text { Halal Food } \\
\text { Awareness } \\
\text { (X) }\end{array}$ & 0,562 & 4,707 & 0,000 & $\begin{array}{l}\text { Positive and } \\
\text { Significant }\end{array}$ \\
\hline
\end{tabular}

Based on table 13, the result of the hypothesis 3 test shown, the effect of halal food awareness on purchase decision for Muslims living in Thailand has positive and significant $(\mathrm{t}=4,707$, Sig. $=0,000<0,05)$. The result provides strong support for hypothesis 3.

\section{Hypothesis 4}

The fourth hypothesis of the model requires a test of religiosity as a moderating variable between halal food awareness and purchase decision.

Table 14 Summary of MRA

\begin{tabular}{ccccc}
\hline Equation $(3): Y i=a+b 1 X i+62 Z i+b 3 X i * Z i+\varepsilon$ & & & \\
\hline Independent Variable & $\begin{array}{l}\text { Standardized } \\
\text { Coefficients Beta }\end{array}$ & t` & Sig & Description \\
\hline Halal Food Awareness & 0,352 & 0,693 & 0,489 & Not \\
(X) & 0,184 & 0,791 & 0,430 & significant \\
Religiosity (Z) & 0,192 & 0,302 & 0,763 & \\
$\left(X^{*} Z\right)$ & & & & \\
\hline
\end{tabular}

Source: Attachment 5 


\author{
Anggraini \& Dewanti \\ The Effect of Halal Foods Awareness on Purchase Decision ...
}

Based on table 14, the result of hypothesis 4 test is rejected. Religiosity cannot strengthen the influence between halal food awareness and purchase decision ( $t=$ 0,302 , Sig. $=0,763>0,05$ ). The result provides that it does not support hypothesis 4 . This result support by the previous study by Machali et al. (2013) which is halal food awareness has no significant effect on purchase decision through religiosity as a mediating variable.

\title{
Have a high-level awareness of halal foods
}

Halal awareness is the level of understanding of Muslims in knowing the issues related to the concept of Halal. Such knowledge includes understanding what is lawful and how the production process of a product according to Islamic halal standards (Nurcahyo \& Hudrasyah, 2017). This result supports previous research by (Machali, et al., 2013) which found the halal food awareness among students in Brunei is significantly high. This result also supports previous research by (Ambali \& Bakar, 2012) which found awareness and concern about halal food among Muslims are gaining impetus in Shah Alam.

\section{The Effect of Halal Food Awareness on Purchase Decision for Muslim Living in Indonesia}

This is an encouraging result because previous research such as (Nurcahyo \& Hudrasyah, 2017); (Machali, et al., 2013) and (Aziz \& Chock, 2013) found that people who are highly religious may not necessarily have a high level of awareness about halal food. The majority of respondents is largely dominated by aged 17 to 23 years and they are can decide their purchases personally, in this case, they realize that they are very cautious related to halal foods. This means that the higher halal food awareness, the more will be their concern to ensure that the food they eat conforms to halal requirements.

\section{The Effect of Halal Food Awareness on Purchase Decision for Muslim Living in Thailand}

Living in Muslim minority countries makes customers be aware of a product and then build and intention of purchase. This means that awareness is a key factor for a Muslim living in Muslim minority countries when assessing foods. The result of this study strengthens the research of (Soesilowati, 2010) which found Muslim respondents consistently put a high priority on the halal issue when they purchase food, buy meat, or select a restaurant. This result also strengthens the research of (Machali, et al., 2013) which found the higher the awareness, the higher the purchase decision.

\section{The Effect of Religiosity as Moderating Variable between Halal Food Awareness and Purchase Decision}

Based on descriptive statistical analysis, religiosity has a very strong agreement by Indonesian and Thai respondents. This indicates that the respondent has a very high level of religiosity, so that religious life has been deeply embedded in him. The result also agrees with the previous study by (Machali, et al., 2013) which indicates religiosity as a moderating variable has a negative and significant result. Then the result is the 
higher degree of religiosity, weaken the effect of awareness on the purchase decision. Also, this research has result that does not support the hypothesis. Religiosity cannot strengthen or weaken the relationship of halal food awareness to purchasing decisions because Muslims in the majority Muslim countries tend to haver regulations that require every mass product sold in a minimarket or supermarket or another channel distribution must have a halal certificate. So that either the person has high- or low-level religiosity, still buy halal food product.

\section{Conclusion}

Respondent has a high-level awareness of halal foods in Indonesia and Thailand. Because there are proved with the result of descriptive statistics that showed halal food awareness has a total mean 4,04 which means the respondents have a high-level awareness. Halal food awareness has a positive and significant impact on purchase decision for Muslims living in Indonesia because there are proved with the significant value of $t$-test is 0.000 with coefficients $t=10,881$ it means halal food awareness gives a positive impact towards purchase decision of halal food in Indonesia.

Halal food awareness has a positive and significant impact on purchase decision for Muslims living in Thailand because there are proved with the significant value of $t$-test is 0.000 with coefficients $t=10,881$ it means halal food awareness gives a positive impact towards purchase decision of halal food in Thailand. The higher level of religiosity cannot strengthen the effect of awareness on the purchase decision, because the significant value of MRA is 0.763 which means religiosity cannot moderate the effect of Halal Foods Awareness on Purchase Decision.

\section{References}

Abdul-Shukor, S., \& Jamal, A. (2013). Developing Scales for Measuring Religiosity in the Context of Consumer Research. Middle East Journal of Scientific Research 13 (Research in Contemporary Islamic Finance and Wealth Management), 69-74. Retrieved from https://www.idosi.org/mejsr/mejsr13(cifwm)13/12.pdf

Ali, N. \& Wawang, A. (2012). Thai Halal Food Products and International Market. Journal of Karistad Business School, 1(1), 1-36.

Ambali, A. R. \& Bakar, A. N. (2012). People's Awareness on Halal Foods and Products: Potential Issues for Policymakers. Pricedia-Social and Behavioral Sciences, 121(19), 3-25. https://doi.org/10.1016/j.sbspro.2014.01.1104

Amirullah. (2002). Perilaku Konsumen. Yogyakarta: Graha Ilmu.

Arinilhaq, N. (2017). Purchase Intention on Halal Culinary Fast Food in Yogyakarta. Hyrbak Ekonomi \& Studi Pembangunan, 18(2), 116-123. https://doi.org/10.18196/jesp.18.2.4035

Armstrong, K. P. (2012). Principle of Marketing. New York: Pearson Education.

Arsyam, I. (2018). Mie Smyang Mengandung Babi. Retrieved from: http://makassar.tribunnews.com/2017/06/18/mie-samyang-mengandungbabi?page $=2$ 
Ashraf, S., Hafeez, M. H., Yaseen, A. \& Hasnain, A. (2017). Do they care what they believe? exploring the impact of religiosity on intention to purchase luxury products. Pakistan Journal of Commerce and Social Science, 11(2), 428-447. Retrieved from https://scholar.google.com.my/scholar?oi=bibs\&cluster=7315824224870760540\&bt $\mathrm{nI}=1 \& \mathrm{hl}=\mathrm{en}$

Ayuniyyah, Q., Hafidhuddin, D. \& Hambari. (2018). Factors affecting consumers' decision in purchasing MUI Halal-Certified Food Products. Tarkia Islamic Finance and Business Review, 10(2), 122-143. http://dx.doi.org/10.30993/tifbr.v10i2.111

Aziz, Y. A. \& Chock, N. V. (2013). The role of halal awareness, halal certification, and marketing components in determining halal purchase intention among non-Muslims in Malaysia: a structural equation modeling approach. Journal of International Food \& Agribusiness Marketing, 25(1), 1-23. https://doi.org/10.1080/08974438.2013.723997

Baroroh, A. (2008). Trik-Trik Analisis Statistik dengan SPSS. Jakarta: Elex Media Komputindo.

Dharmmesta, B. S., \& Handoko, T. H. (2012). Manajemen Pemasaran Analisis Perilaku Konsumen. Edisi Pertama. BPFE, Yogyakarta.

Djatmiko, T. \& Pradana, R. (2016). Brand image and product price. its impact for Samsung Smartphone Purchasing Decision. Procedia- Social and Behavioral Science, 219, 221-227. https://doi.org/10.1016/j.sbspro.2016.05.009

Engle, J., Blackwell, R. \& Miniard, P. (1995). Consumer Behavior. 8th Ed ed. Orlando: The Dryden Press.

Fam, K. S., Waller, D. S. \& Erdogan, B. Z. (2004). The influence of religion on attitudes toward the advertising of controversial products. European Journal of Marketing, 38(5), 537-555. Retrieved from https://ourarchive.otago.ac.nz/handle/10523/1244

Ghozali, I. (2016). Aplikasi Analisis Multivariate dengan Program IBM SPSS 23. Semarang: Badan Penerbit Universitas Dipenogoro.

Golnaz, R., Zainalabidin, M., Mad Nasir, S. \& Eddie, C. F. C. (2010). Non-Muslims awareness of Halal principles and related food product in Malaysia. International Food Research, 17, 667-674. Retrieved from https: $/ /$ www.google.com/url? sa $=t \& r c t=j \& q=\& e s r c=s \&$ source $=w e b \& c d=\& c a d=r j a$ \&uact=8\&ved=2ahUKEwiDnPvjidbqAhWEYysKHaeLDKwQFjAAegQIBRAB\&url $=$ http $\% 3 \mathrm{~A} \% 2 \mathrm{~F} \% 2 \mathrm{Fpsasir} . u p m . e d u . m y \% 2 \mathrm{~F} 11717 \% 2 \mathrm{~F} 1 \% 2 \mathrm{FNon}-$ Muslims awareness of Halal principles.pdf\&usg=AOvVaw1FXQ2PLxnBHUj3 jSX $\underline{\mathrm{Pw}-5}$

Hair, J. F., Anderson, R. R., Tatham, R. L. \& Black, W. C. (1998). Multivariate Data Analysis. Fifth Edition ed. New Jersey: Prentice Hall.

Kahle, L.R., Kau, A.K., Tambyah, S.K., Jun, S.J., \& Jung, K. (2005). Religion, religiosity, and values: Implications for consumer behavior. Paper Presented at the Australian and New Zealand Marketing Academy Conference

Khraim, H. (2010). Measuring Religiosity in Consumer Research from Islamic Perspective. International Journal of Marketing Studies, 2(2): 166-179. https://doi.org/10.5539/ijms.v2n2p166

Kotler, P. (1995). Marketing Management. Engewood Cliffs. New Jersey: Prentice Hall.

Kotler, Philip \& Keller. (2007). Manajemen Pemasaran, Vol. 1, 12th Edition, PT. Indeks, Jakarta

Lau, T. C., Peng, T. L. \& Choe, K. L. (2013). The moderating effect of religiosity in the relationship between money ethics and tax evasion. Canadian Center of Science and Education, 9(11), 213-220. https://doi.org/10.5539/ass.v9n11P213

Machali, M., Abdullah, H. R. \& Razak, A. L. (2013). The effect of halal foods awareness on purchase decision with religiosity as a moderating variable a study at higher education institutions in Brunei Darussalam. Journal of Science and Education, 1-23. 
Mathew, V. N., Raudah, A. M. \& Nurazizah, S., (2014). Acceptance on Halal Food among non-Muslim Consumers. Procedia-Social and Behavioral Science, 121, 262-271. Retrieved from https://cyberleninka.org/article/n/1069812

Minton, E., Kahle, L. R. \& Kim, C. -H., (2015). Religion and motives for sustainable behavior: A cross-cultural comparison and contrast. Journal of Business Research, 68(9), $1-8$.

Mokhlis, S. (2008). Consumer religiousity and the importance of store attributes. The journal of Human Resource and Adult Learning, 4, 122-133.

Mokhlis, S. (2009). Relevancy and Measurement of Religiosity in Consumer Behavior Research. International Business Research, 2(3): 75-84. https://doi.org/10.5539/ibr.v2n3p75

Momtaz, Y. A., Yahya, N. \& Ibrahim, R., 2011. Moderating effect of religiosity in the relationship between social isolation and psychological well-being. Mental Helath, Religion, \& Culture, 14(2), 141-156. https://doi.org/10.1080/13674676.2010.497963

Nasir, M., Norman, A., Fauzi, S., \& Azmi, M. (2011). An RFID-Validation System for Halal Food. The International Arab Journal of Information Technology, 8(2): 204-211. Retrieved from http://eprints.um.edu.my/2066/

Nazlida M. \& Mizerski, D. (2010). The Constructs Mediating Influence on Buyers and Consumers, Journal of Islamic Marketing, 1(2): 124-135. Retrieved from https://www.emerald.com/insight/content/doi/10.1108/17590831011055860/full/p df

Nizam, A. A. (2011). Perception and Awareness Among Food Manufacturers and Marketers on Halal Food in Klang Valley. Klang Valley: Universiti Putra Malaysia.

Nora, L. \& Minarti, N. S. (2016). The role of religiosity, lifestyle, attitude as determinant purchase intention. International Multidiciplinacry Confrence, 135-148. Retrieved from https://jurnal.umj.ac.id/index.php/IMC/article/view/1172

Nurcahyo, A. \& Hudrasyah, H. (2017). The influence of Halal Awareness, Halal Certification, and Personal Societal Perception Toward Purchase Intention: A Study of Instant Noodle Consumption of College Student in Bandung. Journal of Business and Management, 6(1), 21-31. Retrieved from https: $/ /$ www.google.com/url? $\mathrm{sa}=\mathrm{t} \& \mathrm{rct}=j \& \mathrm{qq}=\& \mathrm{esrc}=\mathrm{s} \&$ source $=\mathrm{web} \& \mathrm{~cd}=\& \mathrm{cad}=\mathrm{rja}$ \&uact=8\&ved=2ahUKEwiy9bTsitbqAhWSWisKHUstBCIQFjAAegQIBRAB\&url=h ttps $\% 3 \mathrm{~A} \% 2 \mathrm{~F} \% 2 \mathrm{Fjournal.sbm.itb.ac.id \% 2Findex.php} \% 2 \mathrm{Fjbm} \% 2 \mathrm{Farticle} \% 2 \mathrm{Fdownloa}$ d\%2F2137\%2F1111\&usg=AOvVaw1 ruSnR0fLnt2TPZun7F5 B

Nurrulhidayah A. F., Yaakob B. C. M., Jamaludin, M. A., Suhaimi, Ab. R. \& Hassan, A. A. (2011). Halal Food Issues from Islamic and Modern Science Perspectives. 2nd International Conference on Humanities, Historical and Social Sciences ICPEDR 17, LACSIT Press, Singapore.

Othman, B., Shaarani, S. \& Bahron, A. (2016). The effect of halal requirement practices on organization performance among food manufactures in Malaysia. International Academic Confrence, $1-18$.

Peter, P. J. \& Jerry C. O. (2013). Perilaku Konsumen dan Strategi Pemasaran. Translated by Diah Tantri Dwiandani. Vol. 1 Ed. 9. Jakarta: Salemba Empat.

Worthington, E. L., Wade, N. D., Hight, T. L., \& Ripley, J. S. (2003). Commitment Inventory-10: Development, Refinement and Validation of a Brief Scale for Research and Counseling, Journal of Counseling Psychology, 50(1): 84-96. Retrieved from https://pdfs.semanticscholar.org/80c4/424da253cc0b2038314a30fdcaa21cc1f4f6.pdf 